\title{
Local Governments as Training Ground for National Political Leadership in Nigeria: A Study of Yewa South Local Government
}

\author{
Ajibade Olalekan Eyitayo * \\ Department of Public Administration Federal Polytechnic, Ilaro, Ogun State Nigeria \\ Email: olalekan.ajibade@federalpolyilaro.edu.ng \\ Olabode Bolanle Motunrayo \\ Department of Public Administration Federal Polytechnic, Ilaro, Ogun State Nigeria
}

Article History

Received: September 19, 2021

Revised: November 10, 2021

Accepted: November 14, 2021

Published: November 18, 2021

\begin{abstract}
The study examines the role of local governments as a training ground for national political leadership in Nigeria expending Yewa South Local Government as a study. Survey research design was adopted in conducting this research and relies on primary and secondary sources for data collection. The population for this study consists of employees of Yewa South Local Government council. The primary data came from the one hundred and six (106) questionnaires that were administered to the respondents. The research showed that local governments serve as a training ground for national political leadership in Nigeria expending Yewa South Local Government as a research. This was further supported when out of 102 respondents sampled, $40 \%$ of the respondents strongly agreed that indigenous government functions as guidance in lieu of national political leadership. The aforementioned was also discovered that local governments have significantly facilitated national political leadership in Nigeria. The paper concludes by saying that ifthe qualities of governance defies in Nigeria are to be transcended, Nigerian frontrunners must eschew self-regarding inclinations and stimulate the conjoint good of the Nigerian people through people oriented governance. The paper therefore recommends that concerted exertions must be geared in the direction of certifying that they are audacious and determined leaders, fortified to tackle these challenges: reviving local governance; guaranteeing resilient democratic culpability; constructing civil society; creating hard-hitting choices amid compressions; decentralizing power to indigenous people; endorsing equality; and undertaking disparity.
\end{abstract}

Keywords: Leadership; Local government; Training; Political; Leaders.

\section{Introduction}

In Sixty centuries of nationhood, the greatest critical challenge antagonizing Nigeria as a nation seems to be dependable leadership. Lots of researchers at one time or the other has questioned why Nigeria seems to find it challenging to discourse her recurrent leadership glitches in spite of copious human and material wealth obtainable at her disposal (Odewale and Benson, 2016). Some have claimed that leadership challenge of the country could be traced from the advent of colonial misadventure in Nigeria, while others lay off such argument on the basis that corruption and lack of vision among past and present leaders of Nigeria culminate to hamper any meaningful effort in the quest for good governance in the country. These leadership challenges are evidenced in political, social and economic instability and the prevalence of ethnic, communal and religious crises, which have bedeviled Nigerian socio economic development. In other words, the staggering wave of violence, insecurity, increasing crime wave, economic recession, coupled with the break in law and order are the attributes to the problem of leadership in Nigeria. Therefore, the quest for good leadership is a sine-qua-non for sustainable development.

Effective leadership is a critical ingredient in achieving organizational success. Leadership gives vision and directions, Leadership influence the followers towards achieving a goal. Government exists primarily to secure lives and properties and to provide services that will make life worth living. Local Governments as third tier government are created to bring government closer to the people at the grassroots and for transformation of lives at the rural level (Odewale and Benson, 2016). One of the ways of bringing government closer to the people at the grassroots is through the delivery of service in a satisfactory, timely, effective and adequate manner. Local Government serves as a form of political and administrative structure facilitating decentralization, national integration, efficiency in governance, and a sense of belonging at the grassroots. However, it is pertinent to state that the kind of political leadership that exists will definitely affect the service delivery at the grassroots level. So also a visionary Leader should be able to act in accordance with the tenets of sustainable development which implies poverty reduction, access to basic health services, and education (Odewale and Benson, 2016).

Though the Constitution emphasized on elected council but most of the state governments hide under the power given to them by law to establish, structure, composition and finance to redirect especially the political structure and composition of political leadership, in terms of caretaker committee (appointed council) which creates a lot of concern in service delivery at the local level. Political leadership determines the level of efficiency or deficiency in 
provision of social service that is needed at the local level, thus one of the most important indicators in assessing the transformation of local government is the experiences and perceptions the people have about service delivery in their day-to-day lives. The implication of this is for Political Leaders at local level to transform their words into deeds, and thus to prioritize and satisfy the needs of the communities they serve but there are still other factors that affect the political leadership in deliver the service that is expected of them. The study therefore examines local governments as a training ground for national political development in Nigeria.

\section{Research Questions}

The study seeks to answer the following questions:

i. Can Local Governments serve as training ground for National Political Leadership in Nigeria?

ii. Has Local Governments facilitated National Political Leadership in Nigeria?

iii. What are the challenges facing Local Governments in serving as a training ground for National Political Leadership in Nigeria?

\section{Research Objectives}

The general aim of the study is to examine local governments as a training ground for national political leadership in Nigeria. The specific aims are:

i. Examine if local governments serve as training ground for national political leadership in Nigeria.

ii. Verify the extent to which local governments facilitated national political leadership in Nigeria.

iii. Investigate the challenges facing local governments in serving as a training ground for national political leadership in Nigeria.

\section{Research Hypotheses}

The following hypotheses shall guide this study.

i. Local governments serve as a training ground for national political leadership in Nigeria.

ii. Local governments have significantly facilitated national political leadership in Nigeria.

iii. There are challenges facing local governments in serving as a training ground for national political leadership in Nigeria.

\section{Conceptual Review: Concept of Local Government}

Local Government, according to the United Nations office for public Administration (1976), "is a political sector of a state (in a Federal System) which is established by law and has considerable control of local matters together with the power to enforce taxes and exert labour for set purposes." The guiding principle for the development of Local Government (1976) defined it as "Government at the local level exercised through representative council established by law to exercise particular powers within a defined area". These powers, as it were, should give the councils significant governor of local affairs as well as the institutional financial power to start and direct the provision of services and to define and implement projects so as to complement the activities of the state and Federal Government in their areas and to ensure thorough active participation of the people's traditional institutions, local initiatives and needs are maximized.

Akindele et al. (2000) believes that a Local Government is a subordinate administrative system by means of which the affairs of a particular division and subdivision of a country or state are managed. Mackenzie (cited in Gboyega (2000)) agreed that Local Government serves as a vehicle for training in national governance. This position is informed by the fact that Local Government stood at vintage point in matters relating to the Community which means a firsthand knowledge of issues which improves administration at both state and national levels to gain knowledge of the local communities of their needs and priorities.

Mukoro (2000), argued that, Local Government enables services by local importance only to be locally administered, provides education in citizenship, provides training in political leadership, makes available to the central government information about localities which is essential for adequately meeting needs efficiently and diminishing the concentration of political power by diffusing it. He further opined that these value added, promotes democracy and contributes to the development of a democratic climate. Adamolekun (1983) conceived three objectives of Local Government as an agent of development:

$>$ Firstly, the desire to involve citizens at the grassroots in the management of their own affairs

$>$ Secondly, to ensure that basic needs of local citizen are speedily and efficiently met and

$>$ Thirdly, the provision of frame-work for the management of local resources (human and material) are effectively harnessed and put into productive use for the good of the people.

Ola (1984) also identifies three schools of thought in his functional responsibilities of Local Government. These are the Democratic, Functional and the Development schools. The democratic participation school holds the view that, Local Government functions to bring about democracy and to afford the citizen the opportunity of political participation, political socialization and educate citizens. The democratic and participatory role of Local Government establishes a base for future political actors and leaders that aimed towards national development.

This school of thought according to Ola (1984) places emphasis on how in the developing world Local Government can be an effective agent for better life because it helps to assert governance at local level and thus contributes to national development. Thus, he emphasized about the integration of the functional school to evolve the functional approach which assesses the efficiency and effectiveness of Local Government as a tool for development 
process. He then, suggested two criteria through which functional approach can be used as general category and developmental category. Under general category he identified Democratic Ideas, Political Participation, Protective Service and Infrastructural Services as constituting the major functional items of Local Government. Under the development category, he identified National integration, social, economic development and manpower resources development. Kuklinsky (1971) as cited by Roberts (1997) views local government as a "democratic institution anticipating a wide array of discretionary powers which makes it legally and politically responsive to the needs of the clients within its jurisdiction". Bryne (1994), a British scholar, defined local government as a self-government involving the administration of public affairs in each locality by a body of representatives of local community; although subject to the central government, it still possesses considerable amount of responsibility.

Synopsizing from the above definitions, local government is an institution presiding over a locality or subdivision of a state with devolutionary powers concerned with the administration of public affairs of such locality, by this means, responding to the needs of its people and environment, although subjected to inspectoral super-vision of the state, nonetheless still possesses a considerable degree of responsibility and autonomy. Remarkably, Nigerian Local governments make out with the conceptual definition in terms of structure, not in practice.

\subsection{Concept of Leadership}

Leadership has been well-defined in so many ways that it is hard to come up with a single working definition. Nevertheless, leadership may be defined as a body of people who lead and direct the activities of a group in the direction of a shared goal. It also means the capability to lead, direct and organize a group. In line with this understanding, (Norman and Reed, 2001) defines leadership as a strong mixture of policy and character and strongly stressed that, of the two elements, character as the most ideal for leadership. Gardner (1995), on his part, elucidates leadership as the manner of persuasion or example by which an individual convinces a group to follow objectives apprehended by the leader or shared by the leader and his or her followers. Accordingly, leadership is a procedure of social impact by which a person influences others to achieve an objective and guides the organization in a way that makes it more unified and intelligible (Chemers, 2002). A leader hence is probable to exhibit qualities, which hold but not limited to good character, vision, tact, caution, and aptitude to lead by example because people essentially give credit leadership to those who they feel can most empower them achieve vital goals or objectives. Yukl (2006) defines leadership as "the process of influencing others to understand and decide about what needs to be done and how to do it, and the procedure of enabling individual and cooperative determinations to accomplish shared objectives". The very act of defining leadership as a procedure proposes that leadership is not a characteristic or trait with which only a few certain people are capable at birth. Defining leadership as a process means that, it is a transactional event that happens between leaders and their followers. Viewing leadership as a process means that leaders affect and are pretentious by their followers either positively or negatively. It stresses that leadership is a two-way, interactive event between leaders and followers rather than a linear, one-way event in which the leader distresses the followers but not vice versa. Defining leadership as a procedure makes it accessible to everyone- not just a select few who are born with it. More imperative, it means that leadership is not limited to just the one person in a group who has formal position power (i.e., the formally appointed leader).

Leadership is also characteristically seen as dissimilar to administration although they are related. Kotter (1998) deduced that "management is about handling with complexity" whilst "leadership, by dissimilarity, is about coping with change". He suggested that good administration brings about a degree of order and stability to organizational procedures and goals, whilst leadership is obligatory for vigorous transformation. The discrepancy of leadership from management as characterized by Kotter (1998) and his generations clearly inspire a shift in prominence from the comparatively unbending, bureaucratic procedures characterized as 'management' to the more dynamic and strategic processes classed as 'leadership', yet even he concludes that both are similarly essential for the active running of an organisation:

Leadership is varied from management, but not for the reason most people think. Leadership isn't mystical and mysterious. It has nothing to do with having personality or other unusual personality personae. It's not the province of a chosen few. Nor is leadership necessarily better than management or a replacement for it: rather, leadership and management are two distinctive and complementary activities. Both are essential for success in an progressively complex and volatile business setting Kotter (1998).

Management depends more on planning, organizational and communication skills. Leadership relies on management skills too, but more soon potentials such as integrity, decency, self-effacement, bravery, obligation, genuineness, desire, self-assurance, a positive attitude, wisdom, strength of mind, kindness and sympathy.

Grint (2004) classifies four glitches that make agreement on a mutual definition of leadership highly unlikely. Firstly, there is the 'process' problem - a lack of agreement on whether leadership is resulting from the personal qualities (i.e. traits) of the leader, or whether a leader persuades followership via what he or she does (i.e. a social process). Secondly, there is the 'position' problem - is the leader in charge (i.e. with formally allocated authority) or in front (i.e. with informal influence)? A third problem is one of 'philosophy' - does the leader apply an deliberate, causal effect on the behaviour of supporters or are their seeming activities resolute by context and circumstances or even attributed with hindsight? A fourth toil is one of 'purity' - is leadership exemplified in persons or groups and is it a purely human phenomenon?

Northouse (2010) also classifies four common themes in the way leadership now tends to be conceived: (1) leadership is a procedure; (2) leadership involves inspiration; (3) leadership occurs in a group perspective; and (4) leadership involves goal accomplishment. He thus defines leadership as "a process whereby an individual sways a group of individuals to accomplish a common goal." This is a good definition, but it still finds the individual as the source of leadership. A more communal notion of leadership rises out of a review by Yukl (2002): "Most definitions 
of leadership replicate the assumption that it encompasses a social inspiration method whereby deliberate inspiration is employed by one person [or group] over other people [or groups] to edifice the activities and relationships in a group or organisation" (Yukl, 2002). This definition, however, covers as much as it make known. Just what specifically is the nature of this 'social influence'; how can it 'structure' activities and relationships; and when applied in a group setting who is the 'leader'? In short, leadership is a complex phenomenon that touches on many other significant organizational, social and personal processes. It depends on a process of influence, whereby people are inspired to work towards group goals, not through coercion, but through personal motivation. Leadership is therefore a critical requirement in preserving and promoting the integrity and cohesion of the political community. Leadership could be political, bureaucratic or traditional in form. The constancy and unity of any society is unthinkable without an effective leadership to shape the policy direction of that society (Akande-Adeola, 2013). Leadership includes the achievement of goals. Therefore, leadership is about directing a group of people toward the accomplishment of a chore or the realization of an endpoint through numerous ethically based means. Leaders direct their energies and the vitalities of their followers to the accomplishment of something together.

\subsection{Concept of Political Leadership}

Most people have personal views on who would make a good political leader, but these views are frequently little more than personal decisions about personality or whether a candidate is probable to meet their desires. Amid the numerous features of leadership, political leadership, in particular in the nation - state, inhabits a special position. It is not that it is intrinsically diverse in kind or character from leadership in other organizations, but it is hugely more visible and, ostensibly at least, vastly more important (Blondel, 1987).

Political Leadership refers to the ruling class that stands the responsibility of running the affairs and resources of a political object by setting and manipulating policy priorities affecting the territory through diverse decision-making structures and institutions bent for the arranged growth of the territory. It could also be termed as the human element that functions the machineries of government on behalf of an organized territory. This includes people who hold resolution making spots in government, and people who seek out those positions, whether by means of election, coup d'état, appointment, electoral fraud, conquest, right of inheritance or other means (Ogbeidi, 2012).

Ogbeidi (2012) perceives that, political leadership goes outside the ruling elites that unswervingly manage the affairs of a territory; it holds the totality of the political class that has the capacity to control the machineries of government even from behind the scene. A Blondel (1987) discourse that among the many concerns that political science deals with, the problem of leadership clearly stands out. Leadership is an essential feature of all government and governance: feeble leadership adds to government failures, and strong leadership is indispensable if the government is to be successful. Wise leadership secures opulence in the long run; imprudent leadership may bring about poverty.

Some scholars center on social leadership as a whole, and deal with political leadership as a part among parts (such as Grint (2000); Grint (2005)). Social leadership and political leadership manifest themselves in formal positions and behaviorally. Scholars who stress that political leadership is a special part of social leadership also assert that leadership is 'related to power: a leader (in the behavioral sense) is a person who is able to modify the course of events' (Blondel, 1987; Wildavsky, 2006). There is an connection amid social and political leadership, but the latter is 'thicker' than any other type of social leadership in having a monopolistic or chosen admittance to coercive and persuading hard power, in addition to attracting, persuasive soft power based on ideology, symbolism, ethical/non-ethical character, and perceptions of followers about leaders.

Political leadership implies followership, as well as group tasks to be accomplished through innovative adaptation in a exact condition and institutional cultural context (Bennis and Thomas, 2002; Heifetz, 1994; Tucker, 1995). Leadership-followership is part of the social reality of any group confronting its environment as problematic, in which the group must persistently become accustomed to and innovate. The leadership-followership connections grow.

Kellerman (2004) opines that political leadership denotes control over public policy resolutions. Political leaders develop their power from the fact that they subjugate high office in a legally authorized government, which by virtue of its legitimacy, has the power and ability to choose among stun conventional goals and courses of action. Aransi (2012) is also opines that political leadership lay down broad policies and takes related decisions while the employees of the organization strive to implement same.

Political office-holder is an official type of leader; it is an 'engine' of governmental organization in Nigerian administrative situation.

Akande-Adeola (2013) broadly states that leadership in Nigeria could be observed from two standpoints. One is the constitutional perspective and other one is the unconstitutional perspective. The legitimate perception in the context of this discourse denotes to all positions that are represented in the constitution of the Federal Republic of Nigeria. These include political and bureaucratic offices to be occupied either through election or appointment as the case may be. For example, the office of the President, State Governor, Local Government Chairman, Senate, House of Representatives, State House of Assembly, Local Government Council and a host of others are good case in point of political offices probable at all times to be filled through election. The holders or occupants of these offices are elected from time to time for fixed tenure and subject to restitution for additional term in the case of executive offices and for limitless tenure for the legislative arm of government. Another set of political leaders are ministers, commissioners, supervisory councilors, heads of boards and parastatals, etc. these are leaders selected to deliver partisanbearing for their respective institutions. Bureaucratic offices are those filled through appointment such as permanent secretaries, head of service, directors, civil and public servants and a host of others. While all the preceding signifies constitutionally prescribed offices, unconstitutional leaders are leadership positions not provided 
for in the constitution. Head of private establishments, traditional institutions, religious and ethnic organizations, etc, are not constitutionally prescribed leadership positions. However, this study is limited to political leadership in the formal sector and is expected to serve as a compass in terms of providing policy direction for all citizens and to encourage their welfare at all times. Akande-Adeola (2013) also affirms that Political leaders can either be elected or chosen within the formal setting with the obligation to increase the leading edge of the welfare of citizens either through the enterprise of law making or the situating into practice of those law validly made by the competent organ of government.

Some scholars decided that political leadership could be either elected or appointed (such as (Akande-Adeola, 2013; Aransi, 2012) and similarly, Lamidi and Adeyeye (2013) also agrees that political office holders could be elected or chosen. Aransi (2012) also stresses that for both elected and chosen local councils, leadership play a very significant role. In fact, the leadership styles of the elected and appointed local council executives differ. The leaders are understood as signs of some sort for the local councils. In selected local councils, for example, the sole administrators or the chairmen, concierge committees are the leaders from whom all other representatives of the local government councils take directives.

\section{Political Leadership at the Local Government Level in Nigeria}

The idea of leadership has been well-defined by numerous scholars. It is a phenomenon in all domains of life. As accurately perceived, several scholars have proven their understandings on this concept, by so doing, explanations unveil disparities. Conversely, as voluminous as the literatures are, there seems to be more 'disagreement' than 'agreement' (Erero, 2005). However, the disagreement in the several literatures pivots on the enquiry of who can be rightly considered as a leader, a mere 'head' or 'office holder' and their distinctions.

In the field of management, scholars have claimed on whether leaders are born or made. Leaders, who are born, are referred to the charismatic type of leaders who possessed both incredible and fantastic natural gifts in leading irrespective of any overwhelmed condition. On the other hands, behavioural scientists have dismissed the idea that leaders are born. These scientists assert positively that an individual can be best trained to become a leader. However, scholars have established the two positions that leaders are both born and made, given the example that a person born with leadership characters needs to go through teaching so as to become a better leader.

Social scientists stated that two types of leaders exist in all institutions namely: Official and Unofficial (Stogdill, 1948). A discrepancy could be made amongst the two types. On one hand, the unofficial tends to be intermittent, becoming active at times of crisis and quiescent in more placid circumstances. On the other hands, official leader is are putable person who designs, panels and motivates the dependents to work in the direction of aims which are considered by organization as desirable. Political office-holder is an official type of leader; it is an 'engine' of governmental organization in Nigerian administrative situation.

Leadership is a situational feature because persons who are leaders in one circumstance may not inevitably be leaders in other situations. As a result, the leader of a group is the genus of person which the specific group in its particular predicament necessitates. Hence, leader subjugates a position of 'centrality' in the focal point for the activity of his group.

Tactically, leaders must be able to study their environment to define how best to use the present resources and competences of the organisation. For this reason, a political office-holder must be able to generate his management style; recognize organisational objectives and pursue to implement them commendably; strategize and establish well; direct its resources in most scientific manner desirable; and provide a democratic leadership which is built on the approval of the concept of authority and making resolutions amongst other factors in a democratic way.

\subsection{Challenges of Leadership in Nigeria}

Nonexistence of Rule of Law: In Nigeria, the leaders do not display respect to the rule of law, particularly, judicial choices. This hinders the judiciary to efficiently release its obligations. The probability of the judiciary is not yet genuineness in Nigeria, the political executives be that as it may weaken the unconventionality of the judiciary through support activities, and judicial administration is categorized by breakable implementation capability.

Deficiency of Development Oriented Leadership: Several spectators of the improvement and predicament in Nigeria since independence come to an agreement that poor management has been a most important factor. Most of the Nigerian leaders were not dedicated to improvement of the social order. Existing indications in the advance literature on transformational leaders who have meaningfully abridged poverty in their own countries in the course of the previous quarter century does not produce any reliable deduction concerning the issues that added to the achievements.

Lack of Responsibility and clarity: There is total nonexistence of obvious and answerable leadership in Nigeria. A government is considered to be accountable when its leaders (both elected and appointed) are responsive to the requests of the citizen. Responsibility is best imposed through the implements of rule of law and independent judiciary. Citizen can strive for reimbursement in the courts for performances of oversight or directive by a government and its executives. Nevertheless, Nigeria has not done well in this respect; it has been exploitation at all stages. And this corruption is not unrelated with copious index of fragile accountability and nonexistence of transparency. The leaders misuse public office for private advantage.

Corruption: even though corruption is a universal menace, Nigeria seems to suffer enormously from this condition. Everyone seems to be certain that the nation has a culture of corruption; Nigeria is a rich nation floating on oil wealth, but almost none of it gets to the people. The uncountable developments and deficiency of transparency 


\section{Sumerianz Journal of Social Science}

and honesty of our leaders have left Nigeria corrupt as ever. Politicians are obliterated and later re-admitted into their parties, then, what hope for good governance when the leadership is profoundly embedded in corrupt systems.

Electoral Malpractices: This problem has turn out to be a prevalent occurrence in Nigerian politics. In fact, atypical Nigerian believes that elections cannot be won except it is rigged. Yes, this is the magnitude at which our electoral system has depreciated. Electoral malpractice is not a current phenomenon; in fact, it has been in existence since independence and has continued to exist, even, in a modernized fashion.

Lack of Political Will: A political determination is the persuasive force for sound leadership quality, the ability to do what is right, what is pertinent and what is achievable within the context of devoted nationalism. Political will very often means personal or group sacrifices. It hints at the ability to implement policies that have a nationalistic significant and relevant without letting pockets of interest to take away from what should naturally be of national benefit.

\section{Theoretical Framework}

This research dwells comprehensively on structural functionalism theory because the individual is noteworthy not in and for himself, nonetheless in stipulations of his position, his situation in forms of social affairs, and the performance sallied with his position. Hence, political leaders are not there as individual but as leaders in social relations to the society they govern by delivery of service in adequate and effective manner. From the equivalence of human form, just as the physical parts of the human body- the bones, muscles and different core organs- function independently to aid the whole being live, societal assemblies work collectively to reserve society, political leaders as the head should be able to function and lead well by embarking on the guiding principle that will cumulate in the growth of the common and the general public also should give in return by liquidating their constitutional roles to the government. Certain roles are inevitable in establishments and communal organizations which aid the general public in performing and satisfying its functional prerequisites so that the world runs efficiently. Structural functionalism also sets out to take to mean society as a structure with unified parts with every organization carrying out role function.

Political leadership as a structure at the local level has a mandatory functions of delivery service to the citizens at the grassroots and their inability to perform the expected mandatory functions of service delivery in a apt, ample and acceptable way would lead to dysfunctionalism or disorderliness. Structural functionalism theory have pertinent applicability in comprehending and examining governmental leadership; be it chosen or elected executives in terms of service supply in Nigerian local governments. Local governments are structure created in Nigeria to implement explicit functions that will help bring government nearer to the society; and political leaders are the foremost performers in carrying out these particular functions.

\section{Methodology}

This study made use of both primary and secondary method of data collection; data were collected from journals, books, newspaper publications and questionnaire disseminated to the respondents. The study population was made up of the employees of Yewa South Local Government, Ilaro, Ogun state. A cross sectional survey using a self-administered questionnaire was conducted to pull together the data on the target population which is the staff of the local government. A sample of 106 staff of the local government was selected in which only 104 of the respondents returned their questionnaires fully filled.

\section{Results}

The table 9.1 (below) shows Questionnaire distribution and retrieved. Out of the 106 questionnaires administered to the staff of Yewa South Local Government, 102 questionnaires were retrieved. This represents a response rate of $96 \%$. Consequently, data analysis for this study is based on 102 or $96 \%$ of the total administered questionnaires.

Table-9.1. Questionnaire Distribution and Retrieval

\begin{tabular}{l|l|l}
\hline Questionnaire & Frequency & Percentage (f) \\
\hline Retrieved & 102 & 96 \\
\hline Un-retrieved & 04 & 04 \\
\hline Total & 106 & 100 \\
Source: Field Survey (April, 2021).
\end{tabular}

Table-9.2. Sex of the Respondent

\begin{tabular}{l|l|l}
\hline Sex & Frequency & Percentage (\%) \\
\hline Male & 75 & 74 \\
\hline Female & 27 & 26 \\
\hline Total & 102 & 100 \\
\hline
\end{tabular}

Source: Field Survey (April, 2021).

Table 9.2 shows that out of the 102 respondents, 75 representing $74 \%$ are male while 27 representing $26 \%$ are female. 
Sumerianz Journal of Social Science

Table-9.3. Frequency distribution of Age

\begin{tabular}{l|l|l}
\hline Age & Frequency & Percentage (\%) \\
\hline 20 -25 years & 10 & 10 \\
\hline $26-30$ years & 39 & 39 \\
\hline $31-35 y e a r s$ & 25 & 24 \\
\hline 36years and Above & 28 & 27 \\
\hline Total & 102 & 100 \\
\hline Source: Field Survey (April, 2021).
\end{tabular}

Source: Field Survey (April, 2021).

Table 9.3 shows the age distribution of the respondents. From the responses $10 \%$ of the respondents is between age 20-25years of age, $39 \%$ of the respondents belong to age group 26 to 30 years, 24 percent of the respondents are within the age group 31 to 35 years of age, 27 percent of them fall within age 36years and above.

Table-9.4. Frequency distribution of Educational Qualifications

\begin{tabular}{|c|c|c|}
\hline Qualifications & Frequency & Percentage $(\%)$ \\
\hline MSC/MBA & 28 & 27 \\
\hline $\mathrm{HND/BSC}$ & 33 & 32 \\
\hline OND & 30 & 30 \\
\hline Professional Qualifications Others & 11 & 11 \\
\hline Total & 102 & 100 \\
\hline
\end{tabular}

The educational qualifications of the respondents are shown in Table 9.4, it reflected that $27 \%$ of the respondents had MSC/MBA; 32\% had HND/BSC while 30\% had OND and 11\% had professional qualifications.

\begin{tabular}{|c|c|c|}
\hline Rank/Grade Level & Frequency & Percentage $(\%)$ \\
\hline GL 04-06 & 15 & 15 \\
\hline GL 07-09 & 25 & 24 \\
\hline GL 10-12 & 44 & 43 \\
\hline GL 13-15 & 18 & 18 \\
\hline GL 16-17 & - & - \\
\hline Total & 102 & 100 \\
\hline
\end{tabular}

Table 9.5 shows the Rank/Grade level of respondents. The frequency distribution indicated that $15 \%$ of the respondents are in GL $04-06 ; 24 \%$ are in GL07-09 while $43 \%$ of the respondents are on GL10-12, 18\% are on GL 13-15 and non of the respondents on GL 16-17.

\subsection{Analyses of Responses to the Questionnaire}

The second section of the questionnaire focuses on the respondent's view on Local Governments as a training ground for National Political Leadership in Nigeria. Therefore, the analyses of the research questions in accordance with the respondents' opinion are presented hypothesis by hypothesis as shown below:

The questions (on the questionnaire schedule) relating to this hypothesis are:

Question 1 Local governments serve as a training ground for national political leaders?

Table-9.6. Local Governments and Political Leadership

\begin{tabular}{|c|c|c|}
\hline Responses & Frequency & Percentage (\%) \\
\hline Strongly Agree & 41 & 40 \\
\hline Agree & 35 & 34 \\
\hline Undecided & 13 & 13 \\
\hline Disagree & 6 & 06 \\
\hline Strongly Disagree & 7 & 07 \\
\hline Total & 102 & 100 \\
\hline
\end{tabular}

As shown in table 9.6, out of 102 respondents sampled, $40 \%$ of the respondents strongly agreed that local government serves as a training ground for national political leadership; $34 \%$ of the respondents agree while $13 \%$ of the respondents were undecided, $06 \%$ of them disagreed and $07 \%$ strongly disagreed. The analysis shows that on average $40 \%$ agreed that that local government serves as a training ground for national political leadership. By this analysis, it is clear that political leaders are groom from the local government level.

Question 2:National political leaders were groomed from the local government? 
Sumerianz Journal of Social Science

Table-9.7. Grooming of National Leaders

\begin{tabular}{l|l|l}
\hline Responses & Frequency & Percentage (\%) \\
\hline Strongly Agree & 35 & 34 \\
\hline Agree & 55 & 54 \\
\hline Undecided & 05 & 05 \\
\hline Disagree & 07 & 07 \\
\hline Strongly Disagree & - & 07 \\
\hline Total & 102 & 100 \\
\hline Source: Field Survey (April, 2021).
\end{tabular}

Source: Field Survey (April, 2021).

From table $9.7,34 \%$ of the respondents strongly agreed that National political leaders were groomed from the local government; $54 \%$ of them strongly agreed. Also, $05 \%$ was undecided; $07 \%$ of the respondents disagreed and none of the respondents strongly disagreed. Majority of the respondents agrees to this statement.

Question 3:Local governments have facilitated political leadership in Nigeria?

Table-9.8. Local government and Political Leadership

\begin{tabular}{|c|c|c|}
\hline Responses & Frequency & Percentage $(\%)$ \\
\hline Strongly Agree & 43 & 42 \\
\hline Agree & 35 & 34 \\
\hline Undecided & 05 & 05 \\
\hline Disagree & 11 & 11 \\
\hline Strongly Disagree & 08 & 08 \\
\hline Total & 102 & 100 \\
\hline
\end{tabular}

Table 9.8 indicates that $42 \%$ of the respondents strongly agreed that local governments have facilitated political leadership in Nigeria; $34 \%$ of them agreed. $05 \%$ were undecided, $11 \%$ of them disagreed and $08 \%$ strongly disagreed. The analysis implies that majority of the respondents $42 \%$ strongly agreed that local governments have facilitated political leadership in Nigeria.

Question 4:Political leadership structures at local government level have enhanced good governance?

Table-9.9. Political Leadership Structures

\begin{tabular}{l|l|l}
\hline Responses & Frequency & Percentage (\%) \\
\hline Strongly Agree & 50 & 49 \\
\hline Agree & 38 & 37 \\
\hline Undecided & - & - \\
\hline Disagree & 3 & 03 \\
\hline Strongly Disagree & 11 & 11 \\
\hline Total & 102 & 100 \\
\hline Source: Field Survey (April, 2021).
\end{tabular}

From Table 9.9, 49\% of the respondents strongly agreed that political leadership structures at local government level have enhanced good governance; $37 \%$ of the respondents agreed while none of the respondents were undecided, $03 \%$ of the respondents disagree and $11 \%$ strongly disagreed. The implication of this is that there are established structures to enhance political leadership at the local government level in Nigeria.

Question 5:Local governments are institutions that facilitate National Political Leadership?

Table 9.10. Local Governments as Institutions that facilitates National Political Leadership

\begin{tabular}{l|l|l}
\hline Responses & Frequency & Percentage (\%) \\
\hline Strongly Agree & 10 & 10 \\
\hline Agree & 12 & 12 \\
\hline Undecided & 10 & 10 \\
\hline Disagree & 23 & 22 \\
\hline Strongly Disagree & 47 & 46 \\
\hline Total & 102 & 100 \\
\hline rce: Field Survey (April, 2021).
\end{tabular}

Table 9.10 shows that $10 \%$ of the respondents strongly agreed that local governments are institutions that facilitate national political leadership; in the same line of reasoning, $12 \%$ of the responses agreed; $10 \%$ were undecided. $22 \%$ of the respondents disagreed, and $46 \%$ strongly disagreed. $46 \%$ of the respondents strongly disagree that local governments are institutions that facilitate national political leadership. With this, there are clear evidences that local governments are not the only institution that facilitates national political leadership.

Question 6: Lack of good leadership is an impediment to National Political Leadership in Yewa South Local Government? 
Sumerianz Journal of Social Science

Table-9.11. Good Leadership and National Political Leadership

\begin{tabular}{l|l|l}
\hline Responses & Frequency & Percentage (\%) \\
\hline Strongly Agree & 39 & 38 \\
\hline Agree & 28 & 27 \\
\hline Undecided & 13 & 13 \\
\hline Disagree & 12 & 12 \\
\hline Strongly Disagree & 10 & 10 \\
\hline Total & 180 & 100 \\
\hline
\end{tabular}

Source: Field Survey (April, 2021)

Table 9.11 shows that, $28 \%$ of the respondents strongly agreed that lack of good leadership is an impediment to national political leadership in Yewa South Local Government; 27\% of them agreed while 13\% of the respondents were undecided, $12 \%$ of them disagreed and $10 \%$ strongly disagreed. This evidence shows that majority of the respondents were of the opinion that lack of good leadership is an impediment to national political leadership in Yewa South.

Question 7: Without participation in grassroots politics there would be a major challenge in the political leadership of the nation?

Table-9.12. Participation in Grassroots Politics

\begin{tabular}{l|l|l}
\hline Responses & Frequency & Percentage (\%) \\
\hline Strongly Agree & 35 & 34 \\
\hline Agree & 55 & 54 \\
\hline Undecided & 05 & 05 \\
\hline Disagree & 07 & 07 \\
\hline Strongly Disagree & - & - \\
\hline Total & 102 & 100 \\
\hline \multicolumn{2}{|l}{ Source: Field Survey (April, 2021). }
\end{tabular}

From table $9.12,34 \%$ of the respondents strongly agreed that without participation in grassroots politics there would be a major challenge in the political leadership of the nation; 54\% of them strongly agreed. Also, $05 \%$ was undecided; $07 \%$ of the respondents disagreed and none of the respondents strongly disagreed. Majority of the respondents agrees to the statement that grassroots politics would be difficult in a nation if there's no participation. level?

Question 8: The quality of local government leadership is the gradual erosion of power and authority at the local

Table-9.13. Quality of Local Government Leadership

\begin{tabular}{l|l|l}
\hline Responses & Frequency & Percentage (\%) \\
\hline Strongly Agree & 39 & 39 \\
\hline Agree & 22 & 21 \\
\hline Undecided & 35 & 34 \\
\hline Disagree & 06 & 06 \\
\hline Strongly Disagree & - & - \\
\hline Total & 102 & 100 \\
\hline Source: Field Survey (April, 2021).
\end{tabular}

From Table $9.13,39 \%$ of the respondents strongly agreed that the quality of local government leadership is the gradual erosion of power and authority at the local level; $21 \%$ of the respondents agreed. While $34 \%$ of the respondents were undecided, $06 \%$ of them disagreed and none of them strongly agreed. Majority of the respondents strongly agree to the statement.

Question 9:Local leaders play a very important role in National Political Leadership at Yewa South?

Table-9.14. Roles of Local Leaders in National Political Leadership

\begin{tabular}{l|l|l}
\hline Responses & Frequency & Percentage (\%) \\
\hline Strongly Agree & 50 & 49 \\
\hline Agree & 38 & 37 \\
\hline Undecided & - & - \\
\hline Disagree & 3 & 03 \\
\hline Strongly Disagree & 11 & 11 \\
\hline Total & 102 & 100 \\
\hline Source: Field Survey (April, 2021).
\end{tabular}

From Table 9.14, 49\% of the respondents strongly agreed that local leaders play a very important role in national political leadership at Yewa South Local Government; 37\% of the respondents agreed while none of the respondents were undecided, $03 \%$ of the respondents disagree and $11 \%$ strongly disagreed.

Question 10: Local governments are faced with the challenges of Political Leadership in Yewa South? 
Sumerianz Journal of Social Science

Table-9.15. Challenges of Political Leadership in Yewa South

\begin{tabular}{l|l|l}
\hline Responses & Frequency & Percentage (\%) \\
\hline Strongly Agree & 55 & 54 \\
\hline Agree & 42 & 41 \\
\hline Undecided & 05 & 05 \\
\hline Disagree & - & - \\
\hline Strongly Disagree & - & - \\
\hline Total & 102 & 100 \\
\hline Source: Field Survey (April, 2021).
\end{tabular}

From Table $9.15,52 \%$ of the respondents strongly agreed that local governments are faced with the challenges of political leadership in Yewa South; $41 \%$ of the respondents agreed while $05 \%$ of the respondents were undecided, none of them disagreed and none of them strongly agreed. Majority of the respondents strongly agree to the statement.

\subsection{Discussion of Findings}

This research paper examines local governments as a training ground for national political growth in Nigeria. In attaining the purposes of the study, three research questions were conveyed.

In analysing the first hypothesis, it revealed that local governments function as a training ground for national political leadership in Nigeria using Yewa South Local Government as a study. This was additionally buttressed when out of 102 respondents sampled, $40 \%$ of the respondents strongly agreed that local government serves as a training ground for national political leadership.

The subsequent test presented that local governments have meaningfully enabled national political leadership in Nigeria. Conversely, out of 102 respondents sampled, $42 \%$ of the respondents strongly agreed that local governments have facilitated political leadership in Nigeria

The third test revealed that there are challenges facing local governments in serving as a training ground for national political leadership in Nigeria In addition out of 102 respondents sampled, $52 \%$ of the respondents strongly agreed that local governments are faced with the challenges of political leadership in Yewa South.

\section{Conclusions}

This study examined local governments as a training ground for national political leadership in Nigeria. Investigations from this study shows that the Nigerian leaders suffer the greater denunciation for leadership failure in Nigeria but the controlled also have a part of the condemnation because of their several means of inspiring bad leadership for the sake of selfish achievement. If the aspects of leadership challenges in Nigeria are to be surmounted, Nigerian leaders must recoil from selfish predispositions and encourage the conjoint good of the Nigerian people through people oriented leadership.

\section{Recommendations}

Based on the findings and conclusions drawn from the data analysis, this study makes the following recommendations;

i. Effective political leadership is at the heart of effective democracy. Political office-holders are crucial to our shared vision for local governance efficient, accountable, reliable and changing lives for the better.

ii. Concerted efforts must be geared towards ensuring that they are bold and ambitious leaders, equipped to tackle these challenges: reinvigorating local governance; ensuring strong democratic accountability; building civil society; making tough decisions amidst pressures; devolving power to local people; promoting fairness; and tackling inequality.

\section{References}

Adamolekun, L. (1983). Local government system in Nigeria. Heinemann: Ibadan.

Akande-Adeola, M., 2013. "The politics of accessing leadership the nigerian context." In Being paper presented at the annual lecture 2013 series, University of Jos, Jos.

Akindele, S. T., Obiyan, S. A. and Owoeye, J. (2000). The subject matter of political science. College Press and Publisher Ltd: Ibadan.

Aransi, I. O. (2012). Local government administration in comparative perspective: A comparative performance analysis of elected and appointed local councils in Nigeria. Warren Publishing Inc.: USA.

Bennis, W. and Thomas, R. (2002). Crucibles of leadership. Harvard Business Review, 80(124): 39-45.

Blondel, J. (1987). Political Leadership: towards a General Analysis. SAGE Publications London Beverly Hills: Newbury Park-New Delhi.

Bryne, T. (1994). Penguin Books: New York.

Chemers, M. M. (2002). Cognitive, social, and emotional intelligence of transformational leadership: Efficacy and effectiveness. In r. E. Riggio, s. E. Murphy, f. J. Pirozzolo (eds.), multiple intelligences and leadership. Lawrence Erlbaum Associates: Mahwah, New Jersey. 
Erero, J. (2005). Traditional structures in local governance for local development: A study ofIfe East local government area, Osun State, Nigeria, Department of public administration. Awolowo University, Ile-Ife: Nigeria.

Gardner, J. W. (1995). Leaders and followers', in J. Thomas Wren, The leaders companion: Insights on leadership through the ages. The Free Press: New York.

Gboyega, A. (2000). Political values and local government in Nigeria. Malthouse Press: Lagos.

Grint, K. (2000). The arts of leadership. Oxford University Press: New York.

Grint, K. (2004). Leadership: Limits and possibilities. Macmillan: New York.

Grint, K. (2005). Leadership: Limits and possibilities. Macmillan: New York.

Heifetz, R. A. (1994). Leadership without easy answers. 465 vols., Harvard; University Press.

Kellerman, B. (2004). Bad leadership: What it is, how it happens, why it matters. Harvard Business School Press: Boston.

Kotter, J. P. (1998). What leaders really do. In harvard business review on leadership. Harvard Business School Press: Boston.

Lamidi and Adeyeye (2013). An assessment of leadership role of the political office-holders in the 21st century at the Nigerian local government level: A theoretical perspective. Journal of Public Administration and Policy Research, 5(4): 102-08.

Mukoro, A. (2000). The Paradigm and theories of local government administration in Nigeria. In A. Mukoro (Ed) Institutional administration. A contemporary local Government perspective in Nigeria. Malthouse Press Ltd: Lagos.

Norman, S. and Reed, P. J. (2001). Extraordinary leadership: Creating strategies for change. Kogan Page: London. Northouse, P. G. (2010). Leadership: Theory and practice. 3rd Edition edn: Sage Publications Ltd: London.

Odewale, A. D. and Benson, K. S. (2016). Political leadership structure and service delivery in osun state local governments of nigeria: An empirical analysis. Journal of Sustainable Development in Africa, 18(1): 99116.

Ogbeidi, M. (2012). Political leadership and corruption in Nigeria since 1960: A social-economic analysis. Journal of Nigeria Studies, 1(2): 1-25.

Ola, R. O. F. (1984). Local administration in Nigeria. Kegan Paul international: London.

Roberts, F. O. (1997). In Book Titled "Theories of local government and the Nigerian experience".

Stogdill, R. M. (1948). Personal factors associated with leadership: A survey of the literature. Journal of Psychology, 25(1): 35-71.

Tucker, R. C. (1995). Politics as leadership. University of Missouri Press.

Wildavsky, A. B. (2006). Cultural analysis: Politics, public law, and administration Transaction Publishers. Vol. 1.

Yukl, G. (2002). Leadership in organizations. 5th edn: Upper Saddle River: Prentice Hall.

Yukl, G. (2006). Leadership in organizations. 6th edn: Pearson Education: New York. 